\title{
REVISITING COMPANY LAW WITH THE ADVENT OF ETHIOPIA COMMODITY EXCHANGE (ECX): AN OVERVIEW
}

Getahun Seifu *

\begin{abstract}
The historical development of the law of companies shows that this area of the law is evolving and continually changing based on the level of economic development. The law directly dealing with companies, the 1960 Commercial Code of Ethiopia, seems to limit the scope of the law of companies only to private limited companies and share companies, save the partnerships included in the Code. This is a very narrow approach as it leaves out public enterprises simply because they are not recognized under the Code. This article examines the salient features of company law and argues in favour of a broader understanding of the concept. As such, the article vets the main features of private limited companies, share companies, public enterprises and The Ethiopia Commodity Exchange) ECX and shows how the advent of the ECX has challenged the frontiers of the existing legal framework of Ethiopian law of companies. The study argues that ECX is a unique "hybrid-model" which can neither be categorized as a registered company nor as a public enterprise (statutory company) thereby enhancing the challenge to the frontiers of company law as envisaged in the 1960 Commercial Code of Ethiopia.
\end{abstract}

\section{Key words:}

Company law, public enterprise, Ethiopia Commodity Exchange (ECX), public-private partnership, hybrid-model company.

\section{Abbreviations}

ECX Ethiopia Commodity Exchange

PLCs Private Limited Companies

SOEs State owned enterprises

SRO Self-regulatory organizations

- LL.B; LL.M; Manager for Compliance Monitoring and Investigation at ECX; and part-time lecturer in law at St. Mary's University College Faculty of Law and the Faculty of Law of Addis Ababa University. The author gratefully acknowledges constructive comments from colleagues and assessors on earlier drafts of this research. Any opinion expressed in the research remains the personal opinion of the author and shall not be attributed to the institutions where he works. For comments, he can be contacted via e-mail at: getahunseifu@yahoo.com. 


\section{Introduction}

The formation of companies in their modern legal structure (which enables engagement in large-scale economic activities with substantial resources) does not have a long history in Ethiopia. Nearly three decades after the promulgation of the Bankruptcy Law and Company Law in $1933,{ }^{1}$ there was a need for a new law in response to the economic expansion and development as well as the increased inflow of foreign investment at the time. This new law, "[t]he Commercial Code of 1960, created a comprehensive law of business organisations", in the country.

Company law is part of the law of business organisations, and refers to the law that deals with the bringing together of large resources/capital to do business for profit in accordance with a certain law(s) of organization or incorporation. It could be established either by private individuals or private individuals in association with the state or through state ownership. According to the Commercial Code (hereafter "the Code"), a business organisation is defined as "any association arising out of a partnership agreement". ${ }^{3}$ The Code envisages only the types of companies that are conventionally understood to be encompassed by the law of companies. ${ }^{4}$ Apart from defining a business organisation, the Code does not define or describe what is meant by "company". 5 This article argues against the narrow conception of "company law' as envisaged under the Commercial Code and would support a broader reach beyond privately owned companies, as envisaged in the Commercial Code, and argues that company law ought to include the law of public enterprises. ${ }^{6}$ This article makes a modest attempt to inquire into the concept and scope of company law in Ethiopia contrary to the prevailing view. ${ }^{7}$

\footnotetext{
${ }^{1}$ See paragraph 3, item number 3 of the preambular recitals of the Commercial Code of 1960, which refers back to this law.

2 Everett F. Goldberg (1972), 'An Introduction to the Law of Business Organizations', Journal of Ethiopian Law, Vol. 8, No.2, at 495.

${ }^{3}$ Id.; See also Article 210, Commercial Code.

${ }^{4}$ See Article 212 of the Commercial Code as well as the curricula of law schools in Ethiopia. In our law schools, the law of companies is taught as part of the "Law of Traders and Business Organizations", which covers only the relevant provisions of the Commercial Code and its amendments. The other course that covers State owned enterprises and/or State and privately owned companies as well as cooperative societies is taught under the title of "The Law of Public Enterprises and Cooperative Societies."

${ }^{5}$ For the description of the different understandings of what is meant by the term "company", see below.

${ }^{6}$ It is worth noting at this juncture that one can argue solely based on the provisions of the Commercial Code, which provide only a narrow description and conception of
} 
Moreover, this research argues that the horizon of company law is still expanding with the advent of "hybrid model" self-regulatory organisations (SROs) such as the Ethiopia Commodity Exchange (ECX). The advent of such new forms of institutions strengthens the view that the scope of company law has to be revisited with a view to enabling it to effectively achieve its purpose.

Accordingly, the first section of this article provides a brief overview of the concept of company law. The second section discusses the bounds of company law in Ethiopia with analysis of the concept in light of various forms of establishment and operation and the broader understanding of companies alluded to above. It also discusses the fundamental elements of the various forms of companies with the intention of showing that they do not have objectives that are really far apart. The third section focuses on the formation, distinctive features and characteristics of the ECX, as a form of company, and explains the need for a wider conception of company law in the country. Finally, the last part of the research contains conclusions and recommendations on the way forward.

\section{Meaning and Brief Overview of Company Law}

During earlier times, businesses were owned and run by private individuals and some forms of partnerships. ${ }^{8}$ Though the reasons for forming such partnerships

company law. However, as will be elaborated in the subsequent sections, such an interpretation would not solve issues that emerge based on some new developments under Ethiopian law.

${ }^{7}$ It is the view of this author that the curricula of law schools also look at the concept of companies very narrowly that would not equip graduates with the concept(s) adequately. Currently, there is no explicit connection between the courses on "Law of Traders and Business Organizations" and "The Law of Public Enterprises and Cooperative Societies". This leads to the conception that they are (completely) separate courses. That holds true for other stakeholders such as policymakers and the business community. And, this is the main reason that motivated this author to conduct research towards clarifying some of the underlying issues. The author also hopes that this research would encourage more discussion on the matter and tighten the gap so that it would be addressed properly.

8 See H. R Hahlo (1969), Company Law through the Cases (Cape Town/ Wynberg/ Johannesburg: Juta \& Company Limited), pp. 3-9. It provides an interesting overview of the historical development of the law of companies from the Roman times to the 1960s. See also, in general, John P. Davis (1961), Corporations (New York: Capricorn Books), pp. i-xix. Some would argue to trace the idea of partnerships to the very existence of human kind: "The concept of a corporate body [partnership or otherwise] being a different entity from the individuals who collectively form the corporate body is as old as man; it is seen in the family, the tribe and the nation.", P.A 
could vary, some obvious reasons for the formation include: a) mobilizing resources for a business venture that could not have been done without pooled resources; and b) averting the risk the associates do not want or would not afford to take individually. Thus, forming partnership "enables people to do things which would be difficult or impossible for them to do alone". ${ }^{9}$ However, with changes in time and unfolding challenges, these forms of making business failed to meet the test of time and there arose a need to expand the scope and types of organizations for business. It is noted that:

The radical changes in the industrial science made it very difficult, if not impossible, for sole proprietorship and partnership forms to meet the requirements of expanding scale of business. The sole proprietorships and partnerships with limited capital and unlimited liability, limited managerial skill and other limitations could not prove equal to the challenges posed by the changing times. ${ }^{10}$

This shows that the development of company law is related with the emergence and development of industrialization. Needless to state, the term company ordinarily refers to an association of a number of individuals formed for some common purpose. ${ }^{11}$ In law, a company could be defined as a voluntary association of persons formed to achieve some common objectives, having a separate legal entity, independent and separate from its members, with perpetual succession and a common seal, and with capital divisible into transferrable shares. ${ }^{12}$ Thus, the law views most business associations as persons in the sense that the business association is a separate entity with legal rights and obligations separate and distinct from the owners and/or managers of the business (the real people involved with the association). ${ }^{13}$ The real people involved in any business association are the owners/investors (the people who provide the capital and own the business); the managers (the people who manage the business); and the employees (the people who carry out the tasks necessary to

Thomas (1969), Private Enterprise and the East African Company (Dar es Salaam: Tanzania Publishing House), p. ix.

${ }^{9}$ Goldberg, supra note 2, at 495.

${ }^{10}$ D.P Jain (1997), Company Law (New Delhi: Konark Publishers Pvt Ltd., $2^{\text {nd }}$ ed.), p. 17.

${ }^{11} I d$.

12 P.P.S. Gonga (2004), A Textbook of Company Law (New Delhi: S. Chand and Company Ltd., $5^{\text {th }}$ ed.), p. 9. It should be underscored that this definition does not capture special types of companies established by governments, as the definition hinges on the volition element of grouping among founders to constitute a company.

13 Joseph Shade (2006), Business Associations in a Nutshell (St. Paul, MN:

Thompson/West, 2nd ed.), p. 3. 
operate the business, from sweeping the floor to serving as the chief executive officer). ${ }^{14}$

Thus a company has a separate legal personality detached from its members with continuous existence irrespective of changes in membership. That means the insolvency of its members, death or transfer of shares to another individual or person would not affect the continuous existence of a company. Moreover, it owns property or capital in its own name which would be divided among the members in terms of shares/contributions based on their contribution. As a legal person, it can freely transfer these shares/contributions and bring suit or be sued independently. In short, a company can be understood as a person which is "artificial, invisible, intangible and existing only in contemplation of the law."15

Company law, as a domestic law of a given country, certainly shows variations from country to country. ${ }^{16}$ In general, however, the law of companies (the law of business associations) is the field of law concerning companies and other business organisations, and includes corporations, partnerships and other associations which usually carry on some form of economic or charitable activity. ${ }^{17}$ There are various types of companies that can be formed in different jurisdictions, but the common forms of company include: ${ }^{18}$

i. Company limited by guarantee: This is commonly used where companies are formed for non-commercial purposes such as clubs or charities. The members guarantee the payment of certain (usually nominal) amounts if the company goes into insolvent liquidation, but otherwise they will have no economic rights in relation to the company.

ii. Company limited by shares: Being the most common form of company used for business ventures, it is a company in which the liability of each

${ }^{14} I d$.

${ }^{15}$ Jain, supra note 10, p. 18.

${ }^{16}$ See Wolfgang G. Friedman and Richard C. Pugh (eds) (1959), Legal Aspects of Foreign Investment (New York: Columbia University International Legal Studies Programme) for an excellent overview of the forms of business organizations and companies in more than forty countries all over the world. Though there are differences from country to country in the forms of companies, it can be observed that there are several similarities as well.

${ }^{17}$ See, for instance, Companies Law, available at: $<$ http://www.en.wikipedia.org/wiki/Companies_law> visited on March 11, 2010.

18 See Id. See also Keith Walmsley (ed) (2005), Butterworth's Company Law Handbook (UK: Lexis Nexis, $9^{\text {th }}$ ed), p. 23; CCH Editions Limited (1995), British Companies Legislation (London: CCH Editions Ltd,), p. 122; and J. Ola Orojo (1976), Nigerian Company Law and Practice (London: Sweet and Maxwell), pp. 1718 for related discussion on the types of companies in UK and Nigeria. 
shareholder is limited to the amount individually invested by shareholders. Transfer of the shares in such a company to third parties is usually free.

iii. Company limited by guarantee with share capital: This is a hybrid entity, usually used where the company is formed for non-commercial purposes, but the activities of the company are partly funded by investors who expect a return.

iv. Limited liability company: This is a type of company that is characterized by limited liability, management by members or managers, and limitations on ownership transfer of shares in the company.

v. Unlimited liability company with or without a share capital: This is a hybrid entity wherein the liability of members or shareholders for the debts, if any, of the company is not limited to the capital of the company.

vi. Charter corporations: Before the emergence of legislation of modern companies, these were the only types of companies. Nowadays, they are relatively rare, except for very old companies that still survive, or modern societies that fulfil a quasi-regulatory function.

vii. Statutory companies: These are also relatively rare today, but are established by a statute in accordance with the laws of the relevant jurisdiction.

This demonstrates that different countries establish different types of companies based on their respective legal system, economic policy, political ideology, economic realities etc. Apparently, Ethiopia's company law reflects the country's realities, and in effect, it has features that may vary from or have several similarities with the company laws of other countries. This will be reviewed in the next section.

\section{The Bounds of Company Law in Ethiopia}

\section{1- Classification of Companies under Ethiopian Law}

In Ethiopia, company is a form of business organisation as enunciated under Article 210 of the Commercial Code. Article 210(1) defines a business organisation as "any association arising out of a partnership agreement." And the Code defines partnership agreement as follows:

A partnership agreement is a contract whereby two or more persons, who intend to join together and to cooperate undertake to bring together contributions for the purpose of carrying out activities of an economic nature and of participating in the profits and losses, arising out thereof, if any.

It can be easily inferred from this that a business organisation is an "association" of persons, based on a partnership agreement, who bring together their capital to do a business with the objective of obtaining profit. 
The terms business organisation, business association, business enterprise, and business structure could be used interchangeably. ${ }^{19}$ However, there is a need for caution with the term "association" as it is defined under the Civil Code to mean a "grouping formed between two or more persons with a view to obtaining a result other than the securing or sharing of profits." 20 Goldberg indicates that the term "association" is used in Article 210 of the Commercial Code wrongly as the more accurate translation of the term used in the French text would be "grouping". ${ }^{21}$ Certainly, the term "association" as used in the Commercial Code should not be confused with the definition proffered in the Civil Code as the Codes have mutually exclusive purposes in using the terms. Hence, the term "grouping" would have been better to resolve the confusion.

Companies can be classified into numerous forms based on different criteria such as basis of incorporation, liability, number of members, control, ownership and origin. ${ }^{22}$ These grounds of classification and how they should be understood in the Ethiopian context will be reviewed below.

\subsection{1- Classification based on manner of incorporation}

In terms of the manner of establishment or incorporation, companies can either be classified as registered companies or as statutory companies.

\section{a) Registered companies}

A registered company is a company that acquires its legal personality upon registration. Until it is registered fulfilling the legal requirements, it will not be considered as a company with legal personality. ${ }^{23}$ In terms of registration, Article 212 of the Commercial Code covers two types of companies among the forms of business organisation. These are share company ${ }^{24}$ and private limited company. ${ }^{25}$ It has to be underscored that although Article 211 of the Code defines a business organisation as "any association arising out of a partnership agreement", it does not define or describe what is meant by the term "company" apart from indicating that there are only these two types of companies. ${ }^{26}$

${ }^{19}$ See Shade, supra note 13, p. 2.

${ }^{20}$ Article 404, Civil Code of Ethiopia of 1960.

${ }^{21}$ Goldberg, supra note 2, p. 496.

${ }^{22}$ See Jain, supra note 10, pp. 37-55, and Wolfgang F and Richard P, supra note 16, for instance.

${ }^{23}$ Article 8(1), Commercial Registration and Business Licensing (Amendment) Proclamation No.376/2003.

${ }^{24}$ See Article 212 (e) and Articles 304-509, Commercial Code.

${ }^{25}$ See Article 212 (f) and Articles 510-543, Commercial Code.

${ }^{26}$ See Article 212(1) (e) and (f), Commercial Code. 
The phrase "any association arising out of a partnership agreement" seems broad enough at first sight, but closer review shows that it covers only few forms of association or business organisation as it depends on a partnership agreement, which has to be done in writing apart from joint ventures. ${ }^{27}$ In addition to adopting a narrow conception of the term "company", this would categorically exclude the types of business organisations this research argues to include in the realm of business organisations under Ethiopian business laws. This argument will be explored in Section 3.

Registration of companies requires the incorporation of their partnership agreement in the Memorandum of Association and Articles of Association that will govern their operations. ${ }^{28}$ Upon registration, they acquire legal personality to enter into the operational stage. Once established and registered, the organ registering them, the Ministry of Trade and Industry or the relevant regional bureau, recognizes their operations according to the registered memorandum and articles of association.

Should there be any need for amendment, any amendment to these establishing documents (Memorandum of Association and Articles of Association) has to be agreed upon by the members/shareholders ${ }^{29}$ of the companies and registered at the Ministry of Trade and Industry in the same manner as the original establishing documents. ${ }^{30}$ And, in the case of share companies engaged in the financial sector such as banking, insurance and microfinancing, these companies have to be registered by the National Bank of Ethiopia to acquire legal personality. ${ }^{31}$

\section{b) Statutory Companies}

Statutory companies (also known as "public enterprises" or "State owned enterprises, SOEs") are companies that are established by law, as opposed to

${ }^{27}$ See Articles 211 and 214, Commercial Code.

${ }^{28}$ See Articles 211, 221(2), 222(2), 313, 314, 516, 517 and 518, Commercial Code.

${ }^{29}$ Note that the term 'shareholders' is used here just for the sake of convenience. Both the definitional provisions of share company (Article 304) and private limited company (Article 510) speak in terms of 'members'. There are several differences between the rights of such members. In the case of a share company, the members have the right to get, inter alia, a certificate of shareholding (Article 330 et seq.), whereas this is not the case in private limited companies.

${ }^{30}$ Article 8(1), Commercial Registration and Business Licensing (Amendment) Proclamation No. 376/2003.

31 See Article 5(7), The National Bank of Ethiopia Establishment (as Amended) Proclamation No. 591/2008; and Article 5, Banking Business Proclamation No. $592 / 2008$, for instance. 
registered companies which are established by a memorandum of association. ${ }^{32}$ Public enterprises are defined as wholly State owned enterprises established to carry on for gain manufacturing, distribution, service rendering or other economic and related activities. ${ }^{33}$ These are companies that are "formed to carry out some special public undertakings, for example, railways, waterworks, gas, electricity generation, etc." 34 There are several reasons for their establishment that include (a) national security for areas such as defence industries and public transport; (b) revenue raising in particular in events such as where tax collection is difficult or impossible; (c) economic control and self-reliance; (d) lack of private investment in undertakings where large-scale investment is required; (e) equity considerations when private companies fail to function profitably; and (f) the fear of private monopoly situations. ${ }^{35}$ The major characteristics of such public enterprises include public ownership, public control and establishment by a separate law, having distinct legal personality, limited degree of autonomy and public finance. ${ }^{36}$

Public enterprises acquire legal personality upon establishment by Council of Ministers Regulations to be issued pursuant to Article 6 of Proclamation No.25/1992. These establishment Regulations have to contain, inter alia, the name and purpose of the enterprise, the authorized and paid up capital, extent of

32 The fact that public enterprises could be referred to as companies could be inferred from the cross-reference provided by some provisions of Public Enterprises Proclamation No. 25/1992 to the applicability of the Commercial Code such as relating to the powers and duties of auditors of public enterprises and events of winding up and bankruptcy (See for e.g. Article 34 and 46 of this Proclamation). In addition, Article 4 of the Proclamation provides that the relevant provisions of the Commercial Code shall apply where the Proclamation does not provide expressly.

${ }^{33}$ Article 2 (1), Public Enterprises Proclamation No. 25/1992.

${ }^{34}$ See K.C Garg, R.C. Chawla and Vijay Gupta (1998), Company Law (New Delhi: Kalyani Publishers, $9^{\text {th }}$ ed.), p. 38. Writing about the Tanzanian public enterprises, Hermaj says, “. .. the expressions parastatal, public corporation or enterprise [can] be used interchangeably to mean an institution/organisation which is not an integral part of the Government, but which includes an institution, organisation or agency that is wholly or mainly financed and/or owned and controlled by the Government." Mohammed B. Hemraj (2005), 'Formation of Public Enterprises in Tanzania', Company Lawyer, Vol. 26, No. 12, p. 379.

35 See Privatization and Public Enterprises Supervising Agency (July 2008), 'Lessons from Privatization', Biannual News Magazine, Addis Ababa, Privatization and Public Enterprises Supervising Agency, Vol. 1, No. 3, p. 34.

36 Abebe Eshetu (1994), Organisation and Management of Public Enterprises Autonomy versus Control in the Light of Proclamation No. 25, 1992, (Addis Ababa University, Faculty of Law, Unpublished), pp. 4-5. 
liability and supervising authority. ${ }^{37}$ As companies established by Regulations, any change or amendment of the Regulations establishing such statutory companies has to go through the formal procedure of amendment of Regulations by the Council of Ministers.

It can be observed from review of the various Regulations establishing various types of public enterprises in various sectors that statutory companies operate in Ethiopia under three distinct names, i.e., corporations, enterprises and share companies. Prominent examples of corporations include the Ethiopian Telecommunication Corporation, ${ }^{38}$ and the Ethiopian Electric Power Corporation; ${ }^{39}$ examples of companies established as enterprises include the Ethiopian Airlines Enterprise, ${ }^{40}$ Water Works Design and Supervision Enterprise, ${ }^{41}$ Ethiopian Seed Enterprise ${ }^{42}$ and agricultural development enterprises such as Bale Agricultural Development Enterprise, Arsi Agricultural Development Enterprise, and Awassa Agricultural Development Enterprise. ${ }^{43}$ As regards State owned share companies, these are forms of share companies that are 'transitory' in nature as they are in the process of transformation and are waiting for sale to the private sector. ${ }^{44}$ It must be underscored that the power to convert a public enterprise into a share company type of business organization resides in the Council of Ministers by virtue of Article 47(2) (a) of Proclamation No. 25/1992. The capitals of these share companies are divided into shares and totally held as government shares. ${ }^{45}$

${ }^{37}$ See Article 6, 7 and 47 (1) (a), Public Enterprises Proclamation No. 25/1992.

${ }^{38}$ See Council of Ministers Regulations No. 99/2004, Establishing Ethiopian

Telecommunication Corporation.

39 See Council of Ministers Regulations No. 90/2003, Establishing the Ethiopian Electric Power Corporation.

${ }^{40}$ Council of Ministers Regulations No. 92/2003, Establishing the Ethiopian Airlines Enterprise.

${ }^{41}$ Council of Ministers Regulations No. 110/2004, Establishing Water Works Design and Supervision Enterprise.

${ }^{42}$ See Council of Ministers Regulations No. 100/2004, Establishing the Ethiopian Seed Enterprise.

${ }^{43}$ Privatization and Public Enterprises Supervising Agency, supra note 33, pp. 17-27.

${ }^{44}$ See Article 5, Privatization of Public Enterprises Proclamation No. 146/1998.

${ }^{45}$ See Article 5(2), Proclamation No. 146/1998. Note that Article 2(3) of Privatization and Public Enterprises Supervising Authority [Agency] Establishment Proclamation No.412/2004 defines a share company to mean a company partially owned by the State but excluding those share companies in which the State owns shares through public enterprises. This definition amends the total ownership provision under Proclamation No. 146/1998 and Proclamation No. 277/2002 and introduces the possibility of joint ventures with the government in the event of partial privatization. 
Turning to a short historical synopsis of public enterprises in Ethiopia, the institutional framework under which economic enterprises operated prior to 1974 was a free enterprise system with an open policy in the sense that no minimum requirement was imposed on the establishment and operation of enterprises. ${ }^{46}$ With the taking of power by the Dergue in 1974 and owing to the Marxist-Leninist political ideology that influenced policies and laws, many privately owned companies were nationalised and became public enterprises ${ }^{47}$ through a series of laws. The situation of public enterprises and the economy during this regime is well captured as follows:

Since the middle of the seventies, public enterprises became one of the significant facets of the Ethiopian economy. Pursuing its economic and political policy of centralism, the Dergue regime expropriated private owners and nationalized large and medium scale enterprises in the productive, service and financial sectors... At the end of the seventies, the economy to a large extent was under the dominance of the socialist state and over 200 large public enterprises were operational. These enterprises accounted for over 20 per cent of Ethiopia's GDP. In some sectors, like manufacturing, mining, power and transport, the share of public enterprises added up to over 50 per cent of the total production. ${ }^{48}$

With the demise of the Dergue regime, the incumbent government adopted a market oriented economic policy that gives prevalence to the ownership of property by the private sector. This policy also opened the public enterprises that were in the hands of the government to private sector ownership. That is to say, the public enterprises are being privatised with a view to increasing private sector participation in the market and improving their performance.

In terms of modes of privatization, it should be noted that the types and processes of privatization could differ from one country to another. There are three types of privatization: political privatization, fiscal privatization and economic privatization. In political privatization, all the citizens are provided with share vouchers of state enterprises regardless of their economic viability,

It is also notable that the Ministry of Finance and Economic Development, among the organs of the government, actually owns such shares.

${ }^{46}$ Jesiah Selvam (2007), 'Privatisation Programme in Ethiopia: Is the Cause Justified?' African Renaissance, Vol.4, No.1, 1st Quarter, p. 2, available at $<$ http://ssrn.com/abstract=987606>, visited on October 21, 2008.

${ }^{47}$ Such laws include Proclamation No. 20/75, Proclamation No. 13/77, Proclamation No. 163/79, Proclamation No. 60/78/ and Proclamation No. 156/78. See Abebe E., supra note 36, p. 55.

${ }^{48}$ See Forbes Global Magazine, July 26, 1999 Issue, available at: $<$ http://www.winne.com/ethiopia/to07.html>, visited on July 7, 2009. 
their capital stock and their management while in fiscal privatization, the enterprises are sold to the highest bidder that increases public revenue. ${ }^{49}$ On the other hand, in economic privatization, the government or one of its agencies would manage the restructuring of privatized enterprises and negotiates clauses on employment, social benefits, training and redundancies with other private entrepreneurs. ${ }^{50}$

Just as the reasons for the creation of public enterprises are varied, the reasons for their privatization are also varied. In addition to the failure to meet the original objectives, diminishing profits to the State or continual increase of losses on the State, privatizations of public enterprises are also caused by other internal and external factors. These are (a) higher fiscal pressure on governments (high budgetary deficit, large domestic public debt, and large external debt), (b) higher dependency on loans from international organizations (WB and IMF), (c) a large share of SOEs in total investment, (d) inferior and poor performance of SOEs in production and profitability, and (e) lower long term growth. ${ }^{51}$

Although the incumbent government started with the privatization of some 224 public enterprises inherited from the previous regime, ${ }^{52}$ the number of public enterprises increased for some time but is diminishing at present due to the privatization schemes. Since 1995 alone, "tenders of 308 enterprises and their branches have been floated so as to transfer them to the private sector. Among these enterprises $276(89.6 \%)$ of them have been transferred to the private sector" ${ }^{, 3}$ in the manufacturing, agro-industry, mining, hotels and tourism and trading. ${ }^{54}$

The process of preparing public enterprises for (private) market and competition takes different stages through what is known as commercialization

\footnotetext{
${ }^{49}$ Privatization and Public Enterprises Supervising Agency, supra note 33, p. 33.

${ }^{50}$ Ibid, p. 34.

${ }^{51}$ Selvam, supra note 46, p. 3.

${ }_{53}^{52}$ Ibid, p. 4.

${ }^{53}$ Privatization and Public Enterprises Supervising Agency (March 2008), 'Investment Opportunities in the Ethiopian Privatization Programme', Privatization and Public Enterprises Supervising Agency, Addis Ababa, p. 13.

${ }^{54}$ Note that some 84 public enterprises are also slated for privatization in the coming 3 to 4 years through equity participation (competitive bidding or joint venture) and non-equity participation (management contract or lease of existing facilities). See Ibid, pp. 15-20.
} 
and corporatization. ${ }^{55}$ The stage of commercialization refers to a process directed at establishing private sector management principles, values, practices and policies within public sector organization without involving the private sector at all. ${ }^{56}$ Corporatization, on the other hand, refers to the legal process of converting an entity into a company although initially the State is the sole 'shareholder'. ${ }^{57}$ Relating to this, Article 1(2) of the Privatization of Public Enterprises (Amendment) Proclamation No. 182/1999 provides that an enterprise converted into a share company shall cease to exist upon registration as share company and be replaced by the company. ${ }^{58}$

It is plain to conclude from this that once a public enterprise is converted into a share company and is registered as such, the Commercial Code should normally apply to the company. This is affirmed by Article 5(4) (c) of Proclamation No. 146/1998 where it is stated that the Commercial Code is mutatis mutandis applicable. ${ }^{59}$ Such State owned share companies include the companies engaged in beverages industry (e.g. Awash Winery S.C and Bedele Brewery S.C), food industry (e.g. Faffa Food S.C and Kality Food S.C) and textiles such as Akaki Textiles S.C. ${ }^{60}$

\subsection{2- Classification based on extent of liability}

The liability of companies could be limited or unlimited. In unlimited companies, the members are also personally liable for the payment of the companies' liabilities. ${ }^{61}$ Thus when the asset/capital of the company might not

${ }^{55}$ See Stephen Greenberg (2006), The State, Privatization and the Public Sector in South Africa (Cape Town: Southern African People's Solidarity Network and Alternative Information and Development Centre), p. 3.

${ }^{56} \mathrm{Id}$.

${ }^{57} \mathrm{Id}$.

${ }^{58}$ Note, however, that such a share company is regarded still as a form of public enterprise. See the definition of "public enterprise" under Proclamation No. 277/2002 (Public Enterprises Supervising Authority and the Industrial Development Fund Establishment Proclamation) which defines an enterprise to mean an enterprise as defined under Article 2(1) of the Public Enterprises Proclamation No. 25/1992, or a wholly State owned share company.

${ }^{59}$ However, sub-Articles 3 and 4 of Article 5 of this Proclamation dictate that some provisions of the Code such as valuation of contributions in kind, shareholders meetings, appointment of directors, requirement of minimum number of shareholders and deposition of directors' shares as security with the company shall not be applicable to a share company corporatized from a public enterprise, as this form of company is somewhere between public enterprises and a full-fledged share company.

${ }^{60}$ Privatization and Public Enterprises Supervising Agency, supra note 53, pp. 15-20.

${ }^{61}$ See Gonga, supra note 12, p. 27. 
be adequate to meet its liabilities, its creditors could resort to the personal property of the members/shareholders of the company to redeem their claim. It is worth noting that all companies in Ethiopia, be them registered or statutory, are limited liability companies. ${ }^{62}$

It is important to provide at this juncture an overview of the type of liability of business organizations in the Commercial Code. As stated above, Article 210(1) defines a business organisation as any association arising out of a partnership agreement. According to Article 212, only six different forms of business organizations are recognized. These are ordinary partnership, joint venture, general partnership, limited partnership, share company and private limited company. ${ }^{63}$ It has to be noted, however, that Article 213(2) of the Code leaves room for special provisions that would be applicable to cooperative organizations. This would invite the issue of whether cooperative societies should be considered as traders or not. Obviously, cooperative societies are forms of business organizations established with lesser capital investment and slightly varying objectives such as consumer protection and housing construction. Essentially, they are profit-making companies but that is not their sole objective as they would also have objectives of assisting their members socially, economically and culturally. However, Article 6(2) of the Code provides that cooperative undertakings engaged in agricultural or forestry activities are not traders. However, in fact, cooperative societies could engage in several other activities other than agriculture and forestry and possibly fall under the ambit of the Code. ${ }^{64}$

The business organizations under the Code could be further classified as commercial business organizations and non-commercial business organizations. Ordinary partnerships are non-commercial business organizations, while the rest are commercial in their nature. ${ }^{65}$ It has to be underscored that Article 213 is permissive and the other forms of business organizations could also be formed as non-commercial business organizations, and only share companies and private limited companies are commercial in nature. ${ }^{66}$ This argument could be buttressed by Art 10 (1) which provides that business organisations shall be

${ }^{62}$ See Article 304 and 510 of the Commercial Code and Article 7(2) of Proclamation No. 25/1992.

${ }^{63}$ Note that although a joint venture is mentioned as one form of business organization, it is not required to be formed in writing, though it needs to be formed by a contract of partnership as per Article 211 of the Commercial Code and hence does not have legal personality. See Article 272 (3), 210(2) and 214, Commercial Code.

${ }^{64}$ See Cooperative Societies Proclamation No. 147/1998 and Cooperative Societies (Amendment) Proclamation No. 402/2004 for further details.

${ }^{65}$ Article 213, Commercial Code.

${ }^{66}$ See Article 10(2), Commercial Code. 
deemed to be of a commercial nature where their objects under the memorandum of association or in fact are to carry on any of the activities specified as trade in Article 5. That means, if the object of the business organisation does not fall under the activities specified under Article 5 of the Commercial Code, then the business organization is not of a commercial nature.

In terms of liability, these business organizations could be classified into three categories comprising unlimited liability, limited liability and mixed liability business organizations. Ordinary partnerships and general partnerships are unlimited liability business organizations ${ }^{67}$. That is to say, the liability of their members is not limited to the total capital of the organization but could extend to the personal property of its members. Share companies and private limited companies entail limited liability. ${ }^{68}$ The liability of members of these business organizations is limited to the extent of their contribution, and does not extend to the personal property of their members. The last category is the one with mixed liability wherein some of the members bear unlimited liability while others bear limited liability. A limited partnership comprises two types of partners pursuant to Article 296 of the Commercial Code. These are the general partners who are in full liable personally, jointly and severally and limited partners who are only liable to the extent of their contributions. In the event of joint venture, the partners of a joint venture could bear unlimited or limited liability depending on their role in the venture. The manager of a joint venture who is partner is fully responsible for the liabilities of the joint venture as per Article 276(1); but the other partners who are not managers would be liable only to the extent agreed in the memorandum of association. ${ }^{69}$

In sum, members of companies are liable only up to the limited capital amount and they cannot be held liable beyond their share in the company. In the same fashion, the State, as owner of statutory companies, will not be liable beyond the total assets of the company. In other words, in the event that the assets of the company fail to meet the obligations of the company, the (personal) property of the State (and sometimes the State and other shareholders) cannot be utilized to settle the company's liabilities.

${ }^{67}$ See Articles 255 and 280, Commercial Code.

${ }^{68}$ See Articles 304 and 510, Commercial Code.

${ }^{69}$ Article 276 (2), Commercial Code. Note that partners of a commercial joint venture who are not managers but act as managers will be jointly and severally liable as between themselves and the manager pursuant to Article 276(3). 


\subsection{3- Classification in relation with range of minimum membership and capital}

Companies can be classified based on the minimum number of membership and minimum capital. In share companies, the requirement is to have at least five members with a contributed capital of not less than 50,000 Birr. $^{70}$ In the case of private limited companies (PLCs), the number of members cannot be less than two and more than fifty with a capital of not less than 15,000 Birr. ${ }^{71}$

It should be pointed out that in the light of the objectives of establishment of companies, PLCs would be very appropriate for family and small group of friends while share companies would be more appropriate for an expanded participation well beyond friendship or familial ties or connections. That is so because there is no requirement of publicizing the shares in PLCs, through instruments such as prospectus, and the members can easily pool their resources for investment. In the case of PLCs, as the minimum requirement of membership is small, a single individual could hold substantially all the shares and still remain legal in what is commonly referred to as 'one-man company':

One man company is that company where one man holds practically the whole of the capital of the company and in order to meet the statutory requirement of minimum number of members, some dummy names are added. The dummy names which are added are mostly the relatives or friends of the principal shareholder. ${ }^{72}$

Although the one-man company is not a legally allowed form of PLC in Ethiopia, as provided under Article 512(2) of the Commercial Code, it is stated that the value of a share in a PLC could be as low as 10 Birr and a member can hold more than one share. ${ }^{73}$ Thus, if two individuals agree to form a PLC with a capital worth 50 million Birr with value of each share at 10 Birr and one of them owns only one share, then it can be said that the PLC is nearly fully owned and controlled for all practical purposes by a single person. In addition, sometimes a person establishes a PLC (e.g. X and His Family PLC) and controls the whole company as he contributes a lion's share of the capital of the PLC in his name and the remaining part in the name of his children and the children happen to be

\footnotetext{
${ }^{70}$ Articles 306(1) and 307(1), Commercial Code.

${ }^{71}$ Articles 510(2) and 512(1), Commercial Code.

${ }^{72}$ Jain, supra note 10, p. 56. It should also be noted that there are, in fact, countries that allow a single individual to establish a company (though it is a complete misnomer to call a single individual's business a company or association) and legally hold/own all its shares. Though such a company is not recognized by the Commercial Code, oneman forms of PLCs exist, de facto, as explained below.

${ }^{73}$ See Article 512(2) and (3), Commercial Code.
} 
incapable. This form of one-man PLC is bound to happen in particular in family businesses.

In relation to statutory companies (public enterprises), they are wholly owned by the State as provided for under Article 2(1) of Proclamation No.25/1992. ${ }^{74}$ However, this may not be the case where they are converted into share company(ies) and partially privatized. In such an instance, the number of shareholders could be two or any number more than that: the government and the private shareholder(s). It should also be underscored that one cannot rule out the possibility of one-man de facto share companies that would be formed in the same way as the PLCs, with several dummy names included as shareholders.

\subsection{4- Classification based on extent of control: Holding companies and subsidiary companies}

In terms of the extent of control of one company over the other, companies can be classified into holding companies and subsidiary companies. Although this concept of control is covered in the Commercial Code, it is not dealt with in detail. What is meant by holding companies and subsidiary companies and their distinctions can be discussed in light of the provisions of the Commercial Code.

\section{a) Holding Companies}

A holding company, as the name implies, is a company which has control over another company. ${ }^{75}$ A holding company is also known as a parent company. A holding could be determined based on the control the holder plays in terms of capital or the control the holder plays in decision-making through majority in the board of directors. ${ }^{76}$ Under the Commercial Code, the concept of holding is hardly dealt with but there are few provisions on joint holding. This is provided for under Article 344 to prohibit passage of a certain capital limit. It determines the holding of share companies in terms of control on the capital and sub-Article 1 provides " $[\mathrm{w}]$ here ten per cent or more of the capital of one company is held by a second company, the first company may not hold shares in the second company". ${ }^{77}$ This implies that a holding company can have as much a capital as possible but cross-holding is not allowed if one of them holds $10 \%$ or more of the capital of the other company. But if the share is less than $10 \%$, it appears

${ }^{74}$ Note that these forms of companies could be taken as good examples of de jure oneman companies in Ethiopia.

${ }^{75}$ See Gonga, supra note 12, p. 32.

${ }^{76}$ See Ibid, pp. 32-33.

77 See also Article 379 (Audit of the accounts of a holding company), Article 384 (Investigations on the affairs of holding companies and subsidiaries), and article 451 (Accounts of holding companies) of the Commercial Code as the relevant provisions on holdings companies. 
that both of them can cross-hold capital in each other. In the event that their holding capitals exceed the $10 \%$ limit, they will be required to reduce their shares to less than the limit $^{78}$ under the conditions embodied under Article 344(4).

Some economic sectors such as the banking sector, for instance, require extra prudence in their operations. This has compelled Ethiopia to adopt additional laws on top of the Commercial Code to deal with their special nature. ${ }^{79}$ The Banking Business Proclamation No. 592/2008 is such law issued to govern the banking sector more stringently than the other forms of share companies. Article 11 of this Proclamation provides for the limitation on acquisition of shares in banks as follows:

“1) No person, other than the Federal Government of Ethiopia, may hold more than five percent of a bank's total shares either on his own or jointly with his spouse or with a person who is below the age of 18 related to him by consanguinity in the first degree .[...]

3) The amount of shares that may be held in a bank by a company, which is partially or fully owned by persons who have share in the bank, shall be determined by the National Bank.

4) An influential shareholder of any bank may not acquire shares in other banks."

Thus, a person other than the Federal Government may not hold more than 5\% of a bank's share. In addition, Article 2(11) of this Proclamation introduces the concept of an "influential shareholder", who is a person who holds directly or indirectly two percent or more of the total subscribed capital of a bank, and prohibits him from acquiring shares in another bank. Moreover, a company fully or partially owned by persons cannot have a share that exceeds the amount of shares to be determined by the National Bank of Ethiopia. Therefore, the extent of cross-holding is tightly regulated, which makes the role of one (person) bank in another bank reduced.

According to the Commercial Code, a share company is required to keep at its head office a register showing the number and value of shares or debentures held by each director in any holding company of which the company is a subsidiary. ${ }^{80}$ It should further be noted that there are several PLCs established

\footnotetext{
${ }^{78}$ See Article 344(2) and (3), Commercial Code.

${ }^{79}$ Compare Article 513, commercial Code.

${ }^{80}$ Article 360(1) (c), Commercial Code.
} 
as holding companies to other PLCs in Ethiopia. ${ }^{81}$ However, the Commercial Code does not have provisions on the status of holding companies in the form of PLCs. All the sparse provisions in the Commercial Code are in the part of the Code dealing with share companies. Further, the Commercial Code does not provide how events of cross-holding should be administered in the case of PLCs.

\section{b) Subsidiary Companies}

A subsidiary company refers to a situation whereby a company would be auxiliary to another company which would in turn be its holding or parent company. This makes the concepts of holding and subsidiary companies relative concepts as they are interdependent. Just like the holding companies, the Commercial Code does not provide detailed provisions on the concept of subsidiary companies, be they public or private, apart from mentioning them in certain provisions. ${ }^{82}$ Besides, it should be noted here that a subsidiary company too, say, company X could itself be a holding company to company $\mathrm{Y}$ and such chain has to be clearly catered for in the Code in the future. This will definitely have a large bearing on issues of good corporate governance which is critical to advance private investment and attract foreign investment.

\subsection{5- Classification based on type of ownership and reporting obligations}

From the point of view of ownership, companies can be classified as government or State owned and non-government owned. Government owned companies are statutory companies, and the non-government companies refer to companies owned by persons other than the government such as individuals and other legal persons. Non-government companies can further be divided into public and private companies. In this sense, public company refers to share companies that are open for the general public to invest in while private companies refers to private limited companies that are open to a smaller circle such as family members or friends. ${ }^{83}$

With regard to regulatory power that emanates from ownership, public companies present their financial and annual reports to the general assembly of their members/shareholders as their superior organ, ${ }^{84}$ while statutory companies,

${ }^{81}$ This is the state of play in particular in those political party affiliated companies, which are also referred to as "endowments". This will not be dealt with in this research, as it would be beyond the scope of the research.

${ }^{82}$ See, for e.g., Articles 360 (1) (b) and (c), 384 and 556, Commercial Code for the details.

${ }^{83}$ See Gonga, supra note 12, pp. 30-33.

${ }^{84}$ See, for e.g., Articles 419(1) and 446, Commercial Code. 
on the other hand, present their financial and annual performance reports to the Privatization and Public Enterprises Supervising Agency ${ }^{85}$ and through it to the Ministry of Trade and Industry. ${ }^{86}$ This will also have a lot of bearing on the manner in which the different forms of companies have to be administered with the view to promoting the interests of the State in general and the members/shareholders in particular.

\subsection{6- Classification based on place of establishment: Local and foreign companies}

Companies can further be classified as local and foreign based on their place of establishment. ${ }^{87}$ While companies that are established according to Ethiopian law are known as local companies, whether they operate inside or outside their country of incorporation, ${ }^{88}$ others incorporated abroad are called foreign companies. Foreign companies could operate having their principal place of business in Ethiopia or the subsidiary office (of the parent company) based in Ethiopia. Consequently, those companies that are incorporated abroad and whose head office or principal place of business is located in Ethiopia are subject to the provisions of the Commercial Code. ${ }^{89}$ In addition, those companies that are incorporated abroad and which have subsidiary offices or branches in Ethiopia, with permanent representation, shall be subject in respect of each office or branch to the provisions of the Commercial Code. ${ }^{90}$

The Commercial Code requires under Article 557 that if the form of incorporation of a firm/business organization is different from those it recognises, i.e., which differs from those provided for and covered by the Commercial Code, the foreign business organization must be governed by the law of share companies. This would mean that the foreign firm/company shall fulfil the minimum capital requirement; and the governing bodies such as the board of directors, the management, shareholders' meetings etc. This could be

${ }^{85}$ See Article 6(2) (g) and (h), Proclamation No.412/2004 and Article 6, Financial Public Enterprises Agency Establishment Council of Ministers Regulation No 98/2004.

${ }^{86}$ See Article 2(5) of Proclamation No. 412/2004 and Article 15(10) of the Definitions of Powers and Duties of the Executive Organs of the Federal Democratic Republic of Ethiopia Proclamation No. 471/2005

${ }^{87}$ See Goldberg, supra note 2, p. 508, for instance.

${ }^{88}$ See Article 559, Commercial Code.

${ }^{89}$ See Article 555, Commercial Code. Note that the Amharic version speaks in terms of principal 'purpose' of the business instead of the principal 'place' of business.

${ }^{90}$ See Article 556(1), Commercial Code. Note that the Commercial Code applies to all other forms of business organizations that correspond with the forms of business organization in Ethiopia. 
seen as evidence that the Code appreciates the existence of different forms of companies abroad, but still declines to recognise that. This could be an area that requires closer attention as it could be seen as a discouraging factor for entities who want to come and invest in Ethiopia with different forms of establishment. In relation to foreign investment, it should be underlined that the areas under which such foreign companies can invest are restricted only to areas that are open to investment by foreigners. ${ }^{91}$

\section{2- Main Features of Companies in Relation with Profit}

As can be concluded from the foregoing discussion, companies are established to do some form of business. According to Article 10(2) of the Commercial Code, (registered) companies shall always be deemed to be of a commercial nature whatever their objects. In other words, they are always to be deemed as traders and operate a business. ${ }^{92}$

A business is defined as an incorporeal movable consisting of all movable property brought together and organised for the purpose of carrying out any of the commercial activities specified under the Code. ${ }^{93}$ It consists of corporeal elements such as equipment or goods and incorporeal elements such as the goodwill of the business, its trade name, industrial design, patents and copyrights. $^{94}$ As traders, companies are professionally engaged in business activity with the motive of making profit, ${ }^{95}$ which will basically be shared by the members/shareholders.

Statutory companies (enterprises) are also established with the motive of making profit. However, State owned enterprises are primarily needed to serve public interest, and, in principle, the private sector is not believed to have much interest in certain sectors or owing to the public utility of particular sectors. Be that as it may, statutory companies are established with an express motive of making a particular sector more efficient, productive and profitable competing with the private sector. ${ }^{96}$ In the same manner as members/shareholders of a

${ }^{91}$ See Article 560 of the Commercial Code. See also Article 8 of the Investment Proclamation No. 280/2002 and Article 3 of the Investment Incentives and Areas Reserved for Domestic Investors Council of Ministers Regulations No. 84/2003 for areas that are open to foreign investment (and foreign companies) and those that are reserved for domestic investment.

${ }^{92}$ Articles 5 and 125(1), Commercial Code.

${ }^{93}$ Article 124, Commercial Code.

${ }^{94}$ Articles 127 and 128, Commercial Code.

${ }^{95}$ See the chapeau of Article 5, Commercial Code.

${ }^{96}$ See the second paragraph of the preamble, Proclamation No. 25/1992. 
registered company, the State, as owner of these companies, receives dividend at the end of every financial year. ${ }^{97}$

It is pretty clear that registered companies have a profit motive behind their establishment and operation. They are established by private individuals, and in some cases, with certain participation of government through its enterprises. ${ }^{98}$ Normally, a government in its capacity as the representative political entity of the public is not expected to make profit at the expense of its public. However, as discussed above, governments engage in profit making ventures and, to that extent, they play the role of the private sector. But the final gain will be for the public as a government is not expected to have a separate coffer from that of its public. Therefore, from the point of view of private nature, the difference that one can observe is mainly the form of ownership.

\section{Characterization of Ethiopia Commodity Exchange as Company}

It is obvious from the foregoing discussion that the frontiers of company law in Ethiopia shall not be determined based on the provisions of the Commercial Code alone. The law of public enterprises would also be within the bounds of the law of companies. It appears that the scope of the law of companies is expanding further with the advent of new forms such as Ethiopia Commodity Exchange ("ECX" or "the Exchange" hereinafter). It is worthwhile to briefly examine what ECX is; how it is established; how it operates; and how it is similar and/or different from the types of companies discussed thus far with the view to introducing the ECX and highlighting the issue of whether the Exchange could be referred to as a company under the existing laws of the country.

\section{1- Meaning of commodity exchange}

Commodity Exchange could be defined as a "central place where sellers and buyers meet to transact in an organised fashion, with certain clearly specified and transparent 'rules of the game'. In its wider sense, a commodity exchange is any organised market place where trade, with or without the physical commodities, is funnelled through a single mechanism, allowing for maximum effective competition among buyers and among sellers." 99

${ }^{97}$ See Article 2(9) and 31, Proclamation 25/1992.

${ }^{98}$ See, for e.g., Article 2(1) (a), Proclamation 146/2004.

99 Eleni Z. Gabre-Madhin and Ian Goggin (November 2005), "Does Ethiopia Need a Commodity Exchange?: An Integrated Approach to Market Development: Concept Note", p. 6, available at:

$<$ http://www.ecx.com.et/KnowledgeCneter.aspx>, visited on March 12,2010. 
Article 2(5) of Proclamation No. 550/2007 defines a commodity exchange to mean an exchange [place] where standardised commodity-linked contracts are traded. ${ }^{100}$ The contract to be traded at the Exchange is in turn defined as "a standardised agreement to buy or sell a specified commodity, detailing the amount, grade and price of the commodity and the date on which the contract will mature and become deliverable for purposes of trading on the Exchange."101 The ECX, therefore, is established by law to set forth "the rules of the game" for sellers and buyers as well as intermediary actors so that they all compete effectively in a transparent manner in a centralised market.

\section{2- The Core Purposes of ECX: Information Revolution, Social Good...?}

ECX is an institution established with the main objective of providing a fair and equitable marketplace for agricultural commodities, ${ }^{102}$ which are the mainstay and backbone of Ethiopia's economy. The old agricultural marketing system in Ethiopia is fraught with numerous problems, which could be well described as follows:

Ethiopia's marketing system is characterised by high costs and high risks of transacting. These conditions result in only one third of total agricultural output reaching the market and commodity buyers and sellers tend to trade only with those they know, to avoid the risk of being cheated or default. Trade is done on the basis of visual inspection because there is no assurance of product quality or quantity, which drives up marketing costs, leading to high consumer prices. For their part, small-scale farmers, who produce 95 per cent of Ethiopia's output, come to the market with little information and

100 Note Article 2(4), Ethiopia Commodity Exchange Authority Proclamation No. 551/2007 ("Authority Proclamation No. 551/2007" hereinafter), which repeats this definition word for word.

101 Article 2(6), Ethiopia Commodity Exchange Proclamation No. 550/2007.

102 The term "commodity" is defined to mean a product which is interchangeable with another product of the same kind (See Article 2(4) of Proclamation No. 550/2007). As a general rule, however, all commodities are defined by three characteristics. The first characteristic is standardization. This means that one can take one unit of a commodity and replace it with another unit of the same commodity. Thus, commodities are said to be interchangeable. The second characteristic is tradability, which refers to two distinct features: the existence of a robust market place consisting of many buyers and sellers and the unique futures market, a trading structure not found in traditional investments. The third characteristic is deliverability, which refers to the actual physical exchange of a commodity between the seller and buyer. Scott Frush (2008), Commodities Demystified (New York: McGraw Hill), p. 6. 
at the mercy of the merchants in their nearest and only market, unable to negotiate better prices or reduce their market risk. ${ }^{103}$

With the view to curbing this problem, ECX creates an efficient, transparent and orderly marketing system, which serves the needs of buyers, sellers and intermediary actors and promotes the increased participation of small-scale agricultural producers, such as farmers and cooperative societies, by providing them with up-to-date market information that will enable them negotiate better prices for their produce. ${ }^{104}$ The Exchange is a marketing system that will coordinate better, that will link faster, and that will protect the interests of both sides of the trade. ${ }^{105}$

This is expected to fundamentally change the traditional agricultural products trading system into a modern and centralized trading system with grade-specific standardized contracts and with coordinated offers (to sell) and bids (to buy) through a physical trading floor, with face-to-face open outcry bidding, or an electronic order matching system or both. ${ }^{106}$ In terms of economics, it is said that " $[\mathrm{t}]$ he fact of having a single market mechanism to bring together the myriad of buyers and sellers at any point in time effectively results in the greatest concentration of trading for a given good.... This market mechanism ... results in what is known as 'price discovery', that is, the emergence of true market-clearing price for a good at a particular point in time due to the highest possible concentration and competition among buyers and among sellers."107 This would mean that the market will be competitive, products will get their true prices as a result of the competition and at the end of the day pave the way for the producers to get the price they deserve for their produce. The market, rather than varioius actors who strive to obtain their own advantage, will determine what should be paid for a commodity.

103 "Brief Introduction to the Proclamation Establishing the Ethiopia Commodity Exchange" (prepared as an explanatory memorandum for the adoption of the Proclamation), on file with the author, p. 1.

${ }^{104}$ See Article 6(1) and the preamble, Proclamation No. 550/2007.

105 Brief Introduction to the Proclamation Establishing the Ethiopia Commodity Exchange, supra note 103, p. 1.

106 Articles 20(3), 22(1) and 6((2) and (4)), Proclamation No. 550/2007. So far the Exchange is providing the market place for the face-to-face type of outcry bidding but will introduce the electronic order matching system in the future. Note that in the electronic order matching system the persons concluding the contract would not be expected to meet in person. They will do the trade electronically through the Exchange coordinated trading system from wherever they are in the country using their personal identity numbers and related passwords.

${ }^{107}$ Eleni G. and Ian Goggin, supra note 99, p. 6. 
Immediately after trade is executed, the Exchange has the duty to disseminate the price information to the general public through various outlets on a timely basis and may not withhold or delay such information for any reason. ${ }^{108}$ To facilitate this important and market revolutionizing information sharing, ECX has the obligation to operate a public electronic price dissemination system. ${ }^{109}$ Certainly, this will strengthen the price discovery mechanism discussed above. Currently, dissemination of market price information is mainly done on real time basis in spite of the challenges on the part of telecommunication. Certainly, such dissemination will also have positive impact on enabling all actors in the society in general and the poor farmers in particular to make informed decision in price negotiations for their produce.

In general terms, the Exchange aims to provide market integrity (by guaranteeing the product grade and quantity and operating a system of clearing and settling of payments and goods); enhance market efficiency (by operating a trading system where buyers and sellers can coordinate smoothly at minimal costs); create market transparency (by disseminating market information in real time to all market players); and allow risk management (by offering its contracts for future delivery, providing sellers and buyers a way to lock-in prices for delivery of the physical goods at a pre-specified price). ${ }^{110}$ It also provides an additional layer of protection for compliance with its laws by setting up compliance and alternative dispute settlement mechanisms in its structure. ${ }^{111}$

In is clear, therefore, that on top of revolutionizing the agricultural marketing information exchange system, the ECX carries mammoth social-good inspiration with it in favour of those parties that are negatively influenced by the existing market and attempts to mitigate the abject poverty prevailing in the country. In other words, ECX aims at creating a fair market by informing the market and the society about the price movement and related issues on a regular basis and by regulating the conduct of its actors thereby enabling the commodity marketing system to contribute to the country's development.

\footnotetext{
${ }^{108}$ See Article 21 and Article 6 (8) and (3), Proclamation No. 550/2007.

${ }^{109}$ Article 21 (3), Proclamation No. 550/2007.

110 Brief Introduction to the Proclamation Establishing the Ethiopia Commodity Exchange, supra note 103, p. 1

${ }^{111}$ See Article 3.5.8, the Revised Rules of the Exchange No.2/2009, and Article 28 and Article 6(7), Proclamation No. 550/2007.
} 


\section{3- Functional and Legal Aspects of the ECX}

\subsection{1- Demutualized ${ }^{112}$ ownership, membership and management structure}

\section{a) Ownership and control mechanisms}

ECX is an institution established by specific legislation and owned by the government. According to Article 3(1) of Proclamation No. 550/2007, ECX is a wholly State owned market institution, which commenced operation with a government authorised capital of 250 million Birr having its own legal personality. ${ }^{113}$ As a government owned entity, it is supervised by the Ministry of Agriculture and Rural Development ("Ministry" hereinafter) and regulated by the Ethiopia Commodity Exchange Authority ("Authority" hereinafter).

In exercising its supervisory authority, the Ministry has the power to appoint and remove Government representative board directors; fix the allowances to be paid to board directors; appoint external auditors; cause the allocation of the authorized capital of the Exchange; approve audited financial reports of the Exchange; approve capital injection and net profit re-investment plan of the Exchange; evaluate the overall performance of the Exchange and submit studies, to the Council of Ministers, regarding the participation of the private sector in its ownership ${ }^{114}$; approve, in consultation with the board, the annual and long-term corporate targets of the Exchange and follow up their implementation; approve the salary structure of the Exchange without prejudice to the powers and duties given to the board; and perform other functions necessary for the protection of the ownership rights of the State. ${ }^{115}$

The Authority, on the other hand, regulates the day-to-day activities of the Exchange beginning from its establishment. It formulates directives concerning the regulation of the ECX and ensures fair competition among market participants. ${ }^{116}$ As stated under Article 5 of the Authority Proclamation No.

112 The Proclamation establishing ECX does not define what is exactly meant by the term "demutualized", but explains its meaning by stating the roles of the owner of ECX (i.e., the government), of the members of the ECX (i.e., the private sector), and of the management of the ECX, that is drawn neither from the government, the owner, nor from the private sector, the businesspersons at the Exchange.

${ }^{113}$ Article 7, Proclamation No. 550/2007

114 Please, note that the government does not intend to be the perpetual owner of the Exchange. Rather, the law leaves the doors open for the transfer of the ownership of the Exchange if and when the private sector is ready to succeed. The law requires a study to be conducted by the Ministry in this regard. Nonetheless, the Proclamation does not set any timeframe for the said study or the transfer of the ownership to the private sector.

115 Articles 4, 15 and 18(2), Proclamation No. 550/2007.

${ }^{116}$ See Articles 6(3) and 5(1), Proclamation No. 551/2007. 
$551 / 2007$, "[t]he general objective of the Authority is to ensure the development of an efficient modern trading system, and to regulate and control the secure, transparent and stable functioning of a Commodity Exchange and to protect the rights and benefits of sellers, buyers, intermediaries and the general public." According to Article 6 of the same Proclamation, which sets out the detailed powers and duties of the Authority as a governmental regulatory organ, the Authority has the power to recognize and regulate commodity exchanges, members of the Exchange and their associations, designated clearing institutions, designated warehouses and other Exchange actors to promote and protect public interest. In addition, the Authority has the power to prescribe and amend rules of the Exchange, requirements regarding membership, clearing and settlement and contracts to be traded on the Exchange. ${ }^{117}$ Further, the Authority has the power to approve changes in the operations of the Exchange with respect to fees, the trading system, market information dissemination, dispute resolution and security. ${ }^{118}$

A point worth emphasis is that while the Ministry supervises the Exchange only as long as the government investment and ownership is not transferred to the private sector, the Authority regulates the Exchange in as long as the Exchange is alive. It is in the nature of the market that it needs to be regulated irrespective of the ownership of the Exchange. That is simply because the Exchange cannot effectively regulate itself and achieve the desired objectives as will be discussed further later.

\section{b) Membership: Requirements, rights and obligations}

The actual business activity of the Exchange is left to the members to be drawn from the private sector. The Exchange is established for the benefit of members, with permanent seats, to be recruited by the Exchange itself based on criteria to be set by its internal rules and regulations. ${ }^{119}$ According to Article 4(2) of the Revised Rules of the Exchange, individuals, business organizations, public

${ }_{117}^{117}$ Article 12(10), Proclamation No. 550/2007.

${ }^{118}$ Article 30, Proclamation No. 550/2007.

119 See Articles 3(2) and 8, Proclamation No. 550/2007. It worth noting that the Exchange has developed such criteria through the Revised Rules of the Exchange No. 2/2009, which defines a member, under Article 2.1.17, to mean any person recognised as an Exchange actor by the Authority fulfilling the requirements of the Exchange. The Rules of the Exchange are also available at the Exchange's website: $<$ http://www.ecx.com.et/CompanyProfile.aspx\#LR>, visited on March 17, 2010. 
enterprises and cooperatives engaged in trading of commodities ${ }^{120}$ are eligible to become members of the Exchange.

These persons/entities would generally be allowed to acquire a single permanent membership seat ${ }^{121}$ by, inter alia, paying a membership seat price, annual membership maintenance fee and security deposit depending on the applicable membership type; providing necessary documents such as valid business license, value added tax registration certificate and tax identification number; passing a certification exam; and signing an undertaking in which they vow to abide by the laws and rules of the Exchange. ${ }^{122}$ Once a membership applicant passes the review for fulfilment of such requirements, it will be issued with an approval letter, which will be communicated to the Authority for the purpose of recognition. ${ }^{123}$

Upon receipt of the approval letter from the Exchange, the Authority requires the person desiring to be recognised to, among others, provide valid business license, fulfil the minimum financial requirements, prove the minimum educational or business qualification, provide information about the business one is engaged in, submit names and addresses of managers of all its branches, show that the applicant has a well established business and risk management system and prove that the person has never been convicted of any financial offence or any offence which undermines his/her/its integrity. ${ }^{124}$ Verifying these requirements, the Authority issues the applicant with a membership recognition certificate.

As noted above, membership grants a member with the permanent, freely transferrable and exclusive right to trade on the Exchange as well as the

${ }^{120}$ See Article 8(1) (b), Proclamation No. 550/2007, for the limitation on the types of traders allowed to become members of the Exchange. The Proclamation shows that it is only commodity trades, and processors of same, that can be members of the Exchange.

${ }^{121}$ A membership seat is a permanent, freely transferrable and exclusive right to trade on the Exchange as per Article 2.1.18 of the Revised Rules of the Exchange No. $2 / 2009$. These seats of members can be seen as counterparts of shares in a share company, but the members in the case of the Exchange do not have any stake in the profits of the Exchange apart from using the Exchange as a platform for their trade.

${ }^{122}$ See Articles 4.2.2, 4.6.2.3, 4.6.2.4 and 4.6.2.5 of the Revised Rules of the Exchange cum Article 8(2) and (3) of Proclamation No. 550/2007.

${ }^{123}$ See Article 8(1) (a), Proclamation No. 550/2007, cum Article 4.6.4.4, Revised Rules of the Exchange No. 2/2009.

${ }^{124}$ See Article 17, Proclamation No. 551/2007, cum Part 6, Directives of Ethiopia Commodity Exchange Authority, adopted on March 10, 2008. It should be noted that a similar process is used to approve authorised representatives or recognised agents of members as well. 
privilege to participate in the governance of the Exchange through election of member representatives to the board of directors of the Exchange. ${ }^{125}$ Membership also grants members to have their disputes relating to trading at the Exchange resolved through the Exchange Arbitration Tribunal. ${ }^{126}$ As the Exchange operates based on membership, it is unlawful for a person who is not recognised as a member or as a recognised agent of a member to solicit or accept orders for the purchase or sale of any Exchange traded contract on the Exchange. ${ }^{127}$

Moreover, members have numerous obligations towards the Exchange. These obligations include depositing the commodity they want to sell at a warehouse designated by the Exchange; ${ }^{128}$ maintaining accounts with any of the affiliated recognised Exchange clearing institutions and deposit funds before trade day; ${ }^{129}$ granting written notice of power of attorney to the Exchange authorising the Exchange to issue debit and credit instructions to affiliated recognised Exchange clearing institutions for the purposes of clearing and settlement; ${ }^{130}$ liability for non-performance of Exchange traded contracts in accordance with the relevant law; ${ }^{131}$ liability for acts, omissions and failures of any agent acting on their behalf; ${ }^{132}$ and complying with the Rules of the Exchange and other relevant laws. ${ }^{133}$

${ }^{125}$ Article 8(2), (3), (5), (6), Proclamation No. 550/2007, cum Article 4.4.1 and 4.4.2, Revised Rules of the Exchange No.2/2009. Note that there are exceptional categories of members that are called limited members, whose rights are limited as they will be recognised on a transitional basis only for one year and their membership is not transferrable to third party. They will be given limited membership simply because they would not be able to fulfil the financial requirements of membership at the Exchange. These limited members are expected to transition to full membership at the end of the one year of their recognition. This has been implemented by the Exchange on coffee traders hitherto. See Article 4.4.3, 4.4.4 and 4.4.5, Revised Rules of the Exchange No.2/2009.

126 Article 20(1), Proclamation No. 550/2007, cum Article 15, Revised Rules of the Exchange No. 2/2009.

127 Article 20(1), Proclamation No. 550/2007, cum Article 16, Proclamation No. $551 / 2007$.

${ }^{128}$ Article 8.2.1, Revised Rules of the Exchange No. 2/2009.

${ }^{129}$ Article 25(2), Proclamation No. 550/2007.

${ }^{130}$ Article 25(3), Proclamation No. 550/2007.

${ }^{131}$ Article 9(3), Proclamation No. 550/2007.

${ }^{132}$ Article 9(4), Proclamation No. 550/2007.

${ }^{133}$ See Articles 4.5.1- 4.5.15 and 4.11, Revised Rules of the Exchange No. 2/2009. 


\section{c) Operational management}

The operational management of ECX is left for an autonomous and professional management. ${ }^{134}$ In its organisational structure, the Exchange has a board of directors, a chief executive officer, officers in charge of departments and the necessary staff. ${ }^{135}$ As an autonomous and professionally managed institution, neither the government nor the members have the right to assign employees to the Exchange.

Thus, in the words of the establishing law, the ownership, the membership and the management aspects of the Exchange are segregated and demutualized. ${ }^{136}$ Put differently, the government is the owner of the Exchange; the Exchange actually operates for members who could be traders or producers; and the Exchange is managed by autonomous professionals, which come neither from the government nor the members. This demonstrates that the three actors are planned to be mutually exclusive in their respective areas of operation. This is despite the shared board of directors' representation, which will definitely have impact on the autonomy of the management of the Exchange.

\subsection{2- The issue of characterization}

In view of the ownership, membership and management of the institution demutualized as such, the question that arises at this point would be how to characterize the ECX in terms of Ethiopian law. Could it be regarded as a registered company according to the Commercial Code? Is it a statutory company (enterprise) according to the law of public enterprises? Or, is it neither of these, with distinct identity? These issues need some discussion and analysis.

\section{a) ECX as a commercial entity}

ECX itself does not buy or sell commodities, but provides the platform for persons who want to trade or buy and sell commodities. In other words, it facilitates trading activity by other (private) persons who have become members. ${ }^{137}$ In the process, it receives the commodity, after due grading, from a

${ }^{134}$ See Article 18, Proclamation No. 550/2007.

${ }^{135}$ See Article 10, Proclamation No. 550/2007 and Articles 3.5, 3.6 and 3.7, Revised Rules of the Exchange No. 2/2009.

${ }^{136}$ See Article 3(3), Proclamation No. 550/2007.

137 Note that the class of members known as intermediary members can trade for themselves as well as for and on behalf of others (see Article 8(1)(b) of Proclamation No. 550/2007 for example) such as producers who cannot fulfill the criteria of membership. Those people who get represented by intermediary members are called clients. The ECX attempts to reach the poor farmers in this way; for example, the 
seller into its (designated) warehouses as well as the money for the purchase by a buyer into its designated banks. Upon execution of transaction, it clears the transaction to identify who owes what, to whom and settles the transaction by paying the seller its money and delivering the buyer its commodities. ${ }^{138}$ In facilitating trade by paying money to the seller and delivering grade certified commodities to the buyer, the Exchange assures both parties as to the proper performance of the contract and guarantees or insures same. As such, it addresses the problem of defaults and introduces the concept of "zero default" 139 into the spot contracts traded at the Exchange. ${ }^{140}$ In doing so, the Exchange only acts as an intermediary between buyers and sellers or as a commercial broker. According to Article 56(1) of the Commercial Code:

A commercial broker is a person or business organisation who, independently, professionally and for gain, brings parties together for the

farmers can form a cooperative union and supply their products in an organised form as members or as clients of members at the Exchange.

138 See Articles 24 and 25, Proclamation No. 550/2007 and Articles 24-26 of the Authority Proclamation No. 551/2007.

${ }^{139}$ It is worth noting that Article 6(6) of this Proclamation talks in terms of "minimized default risk", which seems to be the case when the Exchange starts trading in futures contracts.

140 Pursuant to Article 22(1) of Proclamation No. 550/2007, there are two types of contracts for agricultural commodities to be traded at the Exchange. These are spot contracts and futures contracts. As per Article 2(15) of Proclamation 550/2007, a spot contract is an Exchange traded contract for immediate delivery of and payment for the commodity. This provision is further clarified by Article 2.1.38 of the Revised Rules of the Exchange to mean an Exchange traded contract for payment on the same day and physical delivery within a maximum of 10 working days from the date of transaction. What essentially makes this a "spot" contract is the fact that the commodity is already deposited at one of the Exchange warehouses and the funds for the transaction had been deposited at one of the Exchange affiliated banks before the transaction. On the other hand, a futures contract is an Exchange traded contract to buy or sell a commodity for delivery of the physical good or commodity at a specified future date (Article 2(10), Proclamation No. 550/2007). Unlike spot contracts, futures contracts do not require the deposition of the commodity to be traded at the Exchange warehouses before trade date. The contract will be concluded with a seller who promises to deliver the commodity within 30 days, 45 days, 60 days, or 90 days terms or even more time. The buyer buys the commodity paying the future price of the commodity, but the Exchange guarantees the delivery of the commodity at the agreed time. In this connection, Article 22(2) of Proclamation No. 550/2007 empowers the Exchange to develop the grade basis, date and place of delivery of the commodities as well as other contractual terms for each contract. It is worth noting that the Exchange has not started trading in futures contracts yet. 
purpose of their entering into an agreement such as a contract of sale, lease, insurance or carriage.

The Exchange is a legal person established to bring together buyers and sellers as well as intermediaries ${ }^{141}$ to enable them negotiate and enter into a contract of sale of goods (commodities) ${ }^{142}$ with the purpose of gaining profit. ${ }^{143}$ This makes the Exchange a commercial broker, and in effect, a trader. ${ }^{144}$ However, while in practice brokerage can take place either at the place of the broker or the buyer or the seller, Article 6(2) of the Exchange Proclamation requires that the transaction take place at the place of the broker in the case of the Exchange. According to this sub-Article, the Exchange is established to provide a centralised trading mechanism in which buyers and sellers are coordinated through a physical trading floor with open outcry bidding or an electronic order matching system or both. Thus, whether the transaction takes place face-to-face or electronically, it has to be conducted via the system of the ECX through its centralised trading mechanism.

As an organization with legal personality established by law to engage in brokerage, it also appears that the Exchange is a type of organization with a commercial nature according to Article 10 of the Commercial Code. However, it is arguable that the Exchange cannot fall under Article 10 of the Commercial Code, as it does not fulfil the language "... objects under memorandum of association or in fact". Looking at the issue from the point of the meaning of business organizations under the Commercial Code strengthens this argument. In this regard, Article 210 requires a business organization to be established by a partnership agreement. Obviously, ECX would not satisfy this legal requirement to qualify as a business organization as per the Commercial Code. It is established by the government as the sole owner, and there is not any sort of

${ }^{141}$ See Article 6(1), Proclamation No. 550/2007.

${ }^{142}$ See Article 22, Proclamation No. 550/2007

${ }^{143}$ See Article 15(6), Proclamation No. 550/2007, which talks about the re-investment of net profit. But there is no explicit provision that elaborates the profit motive as opposed to its social good motive. This being so, one cannot think of "net profit" without that being the objective of the institution. Also as indicated elsewhere, the Exchange collects membership maintenance fee, security deposit, which is interest free but investable by the Exchange for profit, warehouse storage fee, warehouse handling fee, transaction fee and penalty fees, in the event of breaches. See Article 8(4) and Article 30(3) of Proclamation No. 550/2007 and the Revised Rules of the Exchange No. 2/2009 for the detailed rules on these sources of revenues.

144 See Articles 56(2) and 5(19) and (20), Commercial Code. It should also be underlined that as the Commercial Code characterizes "stock" brokers to be traders under Article 5(19) and Article 62, there is no reason not to characterize "commodity" brokers as traders. 
partnership agreement for the allocated capital by the government. It is rather established, unlike public enterprises which get established by Regulations, ${ }^{145}$ by a Proclamation that stands on its own. But this cannot deny the Exchange of acquiring the status of trader as explained above.

\section{b) Non-transfer of profits/dividend to the State}

In addition to being a limited liability institution bearing liabilities only to the extent of its capital, ${ }^{146}$ ECX is a profit-oriented institution. This evokes a question as to who owns the profit. Is it the government, who is the owner of the Exchange, or the Exchange itself, as an independent/autonomous institution? As the Exchange Proclamation does not answer this question directly, there arises a need to interpret its provisions. As discussed above, the government provides a (initial) capital for start up with the possibility of capital injection at a later stage. ${ }^{147}$ However, there is no provision that requires the Exchange to channel/share profits with the State in the form of dividend or otherwise. Buttressing this view, the Proclamation authorizes the Exchange to re-invest its profits and other funds such as the settlement guarantee fund upon the approval of its board of directors and the Ministry. ${ }^{148}$

Unlike public enterprises, there is no provision in the Proclamation that envisages the accrual of dividend to the State from profits that may be obtained by the Exchange. Seen in light of these, the Exchange does not qualify to be called a public enterprise as provided for in Proclamation No. 25/1992, but seems to be a different form of business organization as will be discussed below.

\section{c) Unique public-private shared board of directors' structure}

Structurally viewed, share companies have, among others, board of directors drawn from members/shareholders of the company; ${ }^{149}$ appointed auditors; ${ }^{150}$ and shareholders' meetings ${ }^{151}$ in their management structure. ${ }^{152}$ Public enterprises

145 In fact, it could also be argued that the Council of Ministers establishes public enterprises by Regulations based on the express authority granted to it by the parliament via Article 6 of Proclamation No. 25/1992.

146 Article 9(3), Proclamation No. 550/2007.

${ }^{147}$ See Article 15(6), Proclamation No. 550/2007.

${ }^{148}$ See Article 12(5) and 15(6) respectively, Proclamation 550/2007.

${ }^{149}$ See Article 347 et seq, Commercial Code.

${ }^{150}$ See Article 368 et seq, Commercial Code.

${ }_{152}^{151}$ See Article 388 et seq, Commercial Code.

152 In most jurisdictions, incorporated companies are identified by five basic characteristics: (a) recognition of the company as entity distinct from all its shareholders (legal personality); (b) the flexibility and adaptability of the company form; (c) ease of transferability of investor interest; (d) limited liability for investors; 
(statutory companies), on their part, have an Agency and government appointed boards of management, which includes the board of directors of share companies wholly owned by the State, to follow up their proper operation to meet their establishment objectives. ${ }^{153}$

ECX, as elaborated above, is regulated by the Authority established for that purpose and supervised by the Ministry as the supervising authority. Within its structure, however, it has a board of directors drawn from government representatives, appointed to safeguard the government's capital investment, and representatives of members of the Exchange, appointed to represent and safeguard the interests of the private sector participating in the Exchange. According to Article 11(1) of Proclamation No. 550/2007, the board of directors consists of eleven members, of whom six, including the chairperson, are appointed by the Ministry ${ }^{154}$ and five are elected by the members of the Exchange among themselves. This is another factor that prevents the Exchange from being characterised as either a public enterprise or a share company.

\section{d) ECX as a self-regulatory organisation (SRO)}

The regulatory mechanisms of the Exchange can be divided into two: internal and external. As mentioned above, externally ECX is regulated by the Authority and supervised by the Ministry. These external control mechanisms aim at promoting the public interest and ensuring that the objectives of the Exchange as set out by the owner, government, are achieved.

In terms of internal regulatory mechanisms, in the event where a member of the Exchange or his legal representative fails to observe its obligations, the Exchange has a mechanism for ensuring compliance with applicable laws by

and (e) specialised management, separate from ownership. See J.J. Du Plessis, 'Some International Developments in Company Law: a South African Perspective', Company Lawyer (1993), Vol. 14, No. 11, p. 228. Among these key characteristics, ECX would not easily fulfil the flexibility and adaptability as well as ease of transferability of investor interest characteristics of an incorporated company.

153 See Articles 8, 9 and 2(4) of Privatization and Public Enterprises Supervising [Agency] Establishment Proclamation No. 412/2004 and Article 6, Financial Public Enterprises Agency Establishment Council of Ministers Regulation No 98/2004 in particular.

${ }^{154}$ One may raise the question, if the government has such representation in the policy making organ of the Exchange, i.e., the board of directors, then how demutualised the ownership is and how autonomous the professional management could be. These are legitimate questions but the joint representation in the board of directors is necessitated chiefly due to the shared nature of the ownership and benefits from the Exchange between the State/government and the private sector as well as its hybrid features that emanate from this. 
investigating and taking disciplinary actions. This compliance mechanism is further equipped with a full-fledged in-house arbitral dispute settlement tribunal. ${ }^{155}$ This makes the Exchange a full-fledged SRO that regulates itself before external regulators intervene in its internal affairs. It is obvious to observe from this that there are at least three layers of regulations in the Exchange: (a) the Exchange itself as an SRO, (b) the Authority, and (c) the Ministry. In the spectrum of powers of the Authority, of the Ministry and of the Exchange, one would wonder where the powers of one begins and ends and how possible conflicts of authority could be resolved.

In any event, if the Exchange has the power to regulate itself in this manner, then why is the external control mechanism put in place? The answer is short and simple: the external control mechanisms are necessary because of the inherent conflict of interest issues that would arise if all the control is left to the Exchange alone. This will become very important when the control is viewed from the point of view of the protection of the public interest at stake. In other words, such 'multiple' layers of regulations are needed to avoid conflict of interest, to effectively ensure the integrity of the market and to build the confidence of its stakeholders.

Although one would observe a degree of external and internal control in share companies as well as public enterprises, the extent of the control to be established by using articles of association (in the case of share companies) and possible directives (in the case of public enterprises) would not go as far as conducting investigations proper and taking disciplinary measures on lawbreakers to ensure compliance. Rather, they will rely on the regular law enforcement authorities including the police and the office of the Public Prosecutor. Moreover, they do not have an established legally supported inhouse arbitral mechanism to resolve disputes relating to business transactions and to expedite dispute resolution.

${ }^{155}$ See Article 28 and Article 6(7), Proclamation No. 550/2007. It is worth a remark that ECX is an institution that is legally bestowed with the power to conduct in-house arbitration and resolve disputes between members inter se and members and clients as per Article 15.1 of the Revised Rules of the Exchange No. 2/2009. Unless the Exchange is a party to a dispute, all Exchange traded contracts related disputes have to be handled through the Exchange facilitated arbitration tribunal. This surely will facilitate the resolution of business disputes in an expeditious manner and save the precious times of businessmen that would have been spent by taking their case to the regular courts, which are overly congested by cases, or by going to other arbitral institutions. 


\section{e) ECX as a hybrid-model company}

In light of the discussion above, the Exchange shares some features of registered companies (at least some features of share companies) and other features of statutory companies, but does not wholly fulfill the legal criteria for either of the two. It can thus be characterized as a "hybrid-model" of company in Ethiopia. It could be referred to as a "hybrid-model" because it has some features of public enterprises (at least due to ownership) as well as that of registered companies (at least due to some aspects of its private membership and part of its management structure). But it cannot be characterised as one or the other as it does not meet the full criteria for share companies or public enterprises. In a manner that seems to be in keeping with this, the Exchange characterises itself as 'publicprivate partnership enterprise ${ }^{, 156}$ demonstrating the fact that it has both the private and public elements and that the investment obtained from the government upon its establishment is solely meant for the operation of the Exchange and use by the private sector.

In developing countries, the private sector does not seem to have the strength, readiness and volition to establish and run a commodity exchange that can relieve the market from the age-old commodity marketing system. ${ }^{157}$ In fact, in countries likes Ethiopia, the private sector in charge of the exchange transactions is not expected to be in favour of the establishment of a commodity exchange simply because the existence of a commodity exchange would level the playing field between producers/suppliers, which are by and large the poor farmers, and certain traders, who get unfairly large profits as compared to the farmers who work hard for seasons to produce a given commodity. That is to say, a certain part of the business community will lose part of its established profits if it introduces such a fair and transparent commodity marketing system. ${ }^{158}$

${ }^{156}$ See Company Profile, available at:

$<$ http://www.ecx.com.et/CompanyProfile.aspx\#AAU>, visited on August 12, 2009.

${ }^{157}$ Please, note, however, that there are several commodity exchanges in the developing world, which are established by the private sector in the form of companies though mostly they prove to be unsuccessful. See, for example, the Kenya Agricultural Commodity Exchange Ltd., available at:

$<$ http://www.kacekenya.com>, visited on March 11, 2010; the Multi-Commodity Exchange of India Ltd., available at:

$<$ http://www.mcxindia.com/aboutus/aboutus.htm>, visited on March 11, 2010; and Uganda Commodity Exchange, available at: $<$ http://www.uce.co.ug $>$, visited on March 11, 2010.

${ }^{158}$ Note that, as mentioned above, the fundamental raison d'être of ECX is creating an efficient, transparent and orderly marketing system, which serves the needs of 
A commodity exchange is needed because the commodities market was, and still is, fraught with numerous problems including middlemen who do not usually add any value but rather hinder the market from operating efficiently towards fair benefits to the producers. Such middlemen, who are commonly referred to as delalas (brokers), simply complicate the transaction process by acts such as hoarding products, withholding market information, misinforming the producers about the real market situation, using some cartels etc and make the producers lose benefits they would actually be entitled to had the market been competitive, open and orderly. Moreover, such long chains of transaction, that would not add any value apart from transferring the same commodity in an unfairly broker-dominated manner, would contribute to the deterioration and lower quality of commodities. The ECX mainly aims to, among others, improve such unbalanced relationships in the commodities markets and improve the quality of commodities by shortening the transaction chain and by using standardized grading specifications. ${ }^{159}$

On the other hand, the government could establish a commodity exchange in the form of a public enterprise proper and operate it, but it would not attract the private sector or the business community and achieve the desired goals of a commodity exchange, which are creating a fair, transparent, orderly and efficient marketing system. It would also be difficult to think how the government can involve the private sector in a manner that would bring about these much-desired results. ${ }^{160}$

Without the effective participation of the private sector, a commodity exchange in the form of public enterprise per se would not make sense. Therefore, a joint-pursuit towards public-private partnership would make a good compromise in Ethiopia for two main reasons: (a) it will enable the

buyers, sellers and intermediaries and promoting the increased market participation of Ethiopian small-scale producers. See Article 6(1) and paragraph 2 of the preamble, Proclamation No. 550/2007.

159 Such objectives are being expressly used in subsequent commodity laws such as the Coffee Quality Control and Marketing Proclamation No. 602/2008. While laying down the objectives of the Proclamation, the preamble of the Proclamation expressly states: “... it has been found necessary to make the coffee marketing system fast and cost effective, in order to enable coffee producers to earn better income from coffee transactions; and ....in order to efficiently supply quality and competitive coffee to the global market, it has become necessary to establish an improved system for coffee quality control and marketing".

${ }^{160}$ A case in point is the failure to liberalise the coffee transaction from such unfair marketing system using the defunct Coffee Auction Centre, which was operating under the Ministry of Agriculture and Rural Development until coffee transaction was fully transferred to the ECX by Proclamation No. 602/2008. 
government to create a joint venture with the private sector and achieve its goal of improving and modernizing the traditional marketing system prevailing in the country, and (b) it will ease the fear and suspicion of the private sector to actually invest in such ventures thereby reducing the extent of the risk to be incurred by the private sector and enabling it rather to take advantage of, at a minimal expense, the modern marketing system established by the government. As discussed above, this is exactly what the ECX does. This makes it certain that the ECX cannot be characterised as a public enterprise. If it cannot be a public enterprise, then what can it be? The remaining option in our legal system is share company, among the list of companies, but as discussed above, ECX does not meet the requirements of a share company as well. ${ }^{161}$

The partnership between the public and private sectors indeed is a unique innovation in the country, which would not have happened had it not been for the new legal framework establishing the ECX. The ECX has established an exchange that is considered as "the first of its kind in Africa". ${ }^{162}$ Soon after its establishment, the unique public-private partnership model of ECX is commended by the international community including African States. Subsequently, representatives of several African countries visited the ECX and conferred with the Exchange with the view to sharing experience and trying to adopt the same model in their respective jurisdictions.

In sum, the mutual representation of the government and the private sector, the 'demutualised' ownership, membership and management aspects, the nontransfer of profits of the Exchange as dividend to the State, the SRO nature of the Exchange, the membership recruitment and recognition requirement, and its establishment by a Proclamation as opposed to the establishment of public enterprises by Regulations, inter alia, show that ECX is not a public enterprise proper. And on the other hand, the fact that it is established by the government, the public-private participation in the board of management and the private nature of its membership, among others, show that it is not a company under the 1960 Commercial Code. Nor does ECX share the features of share companies solely owned by the government. The author of this article thus holds that the form of legislation that established the ECX can be regarded as a new variety of company law which widens the horizon of the traditional conception of the company law in Ethiopia, and this warrants revisiting the mainstream conception of the scope of the law of companies in the country.

161 This is one of the main reasons that inspired this research.

162 See Company Profile, available at: $<$ http://www.ecx.com.et/CompanyProfile.aspx> visited on March 12, 2010. 


\section{Conclusion}

There are two different approaches of understanding the scope of company law. The first pursues a narrower and literal interpretation of company law purely based on the terminology used in the Commercial Code, i.e., the description given to 'business organisation' and which depends on the existence of a partnership agreement. The other approach can be a broader definition and understanding of the term "company" in pursuance of purposive and logical interpretation thereby taking the events after the promulgation of the 1960 Commercial Code into account. In the latter conception the term company could also cover entities in the public domain such as public enterprises. Even after adopting the broader understanding of the term company law, it may still become difficult to characterise the ECX as a company under Ethiopian laws.

In terms of merit, the ECX is an institution established by Proclamation to engage in and enhance the traditional commodity trading system by serving as a warehouse, a centralised trading place and trading system, an institution to engage in partial banking services (as it clears and settles transactions via designated banks), medium for real time information dissemination (via an advanced IT system) and a legally recognized alternative dispute resolution $(A D R)$ institution for its members and their clients. Moreover, it is authorised by law to act as a broker between buyers and sellers at its own trading floor. It is not difficult to see, from this range of powers, how much responsibility and importance is given to the ECX to break the age-old traditional trading system of the country that is fraught with abundant precarious problems.

These rewards remaining right, the advent of the ECX has, nevertheless, introduced real challenges to the frontiers of company law in the Commercial Code as well as in the Public Enterprises Proclamation. The requirement of partnership agreement single-handedly excludes the ECX model from the list of business organizations envisaged under the 1960 Commercial Code, as ECX is solely established and owned by the government. This seems to make the traditional classification of companies under the Commercial Code outdated. As such, the ECX model fits neither with the elements of share companies nor with the elements of the law of public enterprises.

In this regard, while elements such as the fact that it is established by the government, with a shared public-private board of management, through the instrumentality of a Proclamation and private membership show that the ECX model does not squarely fit with the features of company under the Commercial Code; elements such as the mutual representation of the government and the private sector; the 'demutualised' ownership, membership and management; the non-transfer of profits/dividend to the State; and establishment by a Proclamation, in contrast to Regulations, show that the ECX model does not squarely fit with the features of a public enterprise. Therefore, ECX is a unique 
"hybrid-model" of company, which borrows some elements from public enterprises and others from registered companies. Even more so, it sounds logical to envisage that this frontier of company law is to be challenged further by the foreseeable introduction of a stock exchange if it is not going to be established in one of the existing forms.

As observed above, statutory companies and registered companies (and even the ECX, to a large extent) share several commonalities including purpose, structure of management and nature of operations with the former carrying more of a public orientation. But the law of companies seems to be heavily fragmented into several laws, among others, the Commercial Code of 1960 and the Commercial Registration and Business Licensing Proclamation No. 67/1997 and its Amendment Proclamation No. 376/2003 as well as regulations issued pursuant to it; the Public Enterprises Proclamation No. 25/1992 and amendments and regulations issued pursuant to it; the Cooperative Societies Proclamation No. 147/1998 and its Amendment Proclamation No. 402/2004; and the ECX Establishment Proclamation No. 550/2007. This research concludes that share companies, private limited companies, public enterprises, cooperative societies and the ECX are various forms of companies existing in Ethiopia although they do not squarely fit into the meaning of business organisations as enunciated in the Commercial Code.

This fragmentation can be rectified through integration and harmonisation in the course of amending the Commercial Code. One way of doing this could be the "constitutional approach" in which the Code recognizes the various forms of companies discussed above and leaves the detailed provisions to other subsidiary or parallel legislation. In such a case, the Code would have to lay the basic common features of what constitutes a company and leave the details to the other legislation. In particular, the definitional provisions dealing with business organisation need to be revisited and broadened. In addition, the amendment process of the Commercial Code is expected to look into the deficiencies in the areas such as the regulation and administration of holding companies and subsidiary companies to share companies and PLCs. This could also be important in bringing about good corporate governance in Ethiopia as it would create more harmony and clarity in responsibilities. 